\section{Vladislav I. Ostrovskiy ${ }^{1}$}

Article info:

Received 01.04.2020

Accepted 23.07.2020

UDC -005.6

DOI - 10.24874/IJQR14.03-20

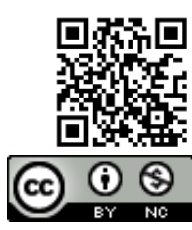

\title{
IMPROVING THE QUALITY OF FOREIGN ECONOMIC ACTIVITY MANAGEMENT OF SMALL AND MEDIUM-SIZED BUSINESSES BASED ON INTERNATIONAL COOPERATION AND INTEGRATION
}

Abstract: This article highlights the trends and patterns of international cooperation and integration of small and medium-sized businesses by the example of the Stavropol territory (Russia), considers the participation of state bodies in international cooperation and exports.

Management of the infrastructure of international cooperation and integration is characterized by low efficiency and is constrained by the lack of scientific and methodological support for these processes. The problem is that the existing needs of small and medium-sized businesses for infrastructure support for international cooperation and integration are unmet, while budget resources are spent on the development of those infrastructure components that are not in demand or can only bring practical benefits in combination with other components.

Scientific novelty consists in the development of scientific and methodological recommendations for optimizing the management of international cooperation and integration of small and medium-sized businesses in the Stavropol territory.

Keywords: International cooperation; International integration; Export; Foreign economic activity; Small businesses; Medium-sized businesses; Quality of management

\section{Introduction}

The modern world economic system is the product of a complex evolution of the system of international economic relations that arose as a result of the deepening of the international division of labour and the development of international specialization and cooperation of production. Moreover, the processes of globalization of economic relations that have been developing in recent decades are accompanied by the integration of countries and regions, their closer cooperation with each other, and the transnationalization of production and finance (Kashbraziev, 2012).

International production cooperation is production linkages between different enterprises located in different countries that arise when a particular product is manufactured.

Economic integration is a process of economic interaction between countries that leads to the convergence of economic

${ }^{1}$ Corresponding author: Vladislav I. Ostrovskiy

Email: ostrovskiyvlad@mail.ru 
mechanisms, takes the form of interstate agreements and is coordinated by interstate bodies. The integration process usually begins with the liberalization of mutual trade, the removal of restrictions on the movement of goods, then services, and capital, and gradually, under appropriate conditions and the interest of partner countries, leads to a single economic, legal, and information space within the region. A new quality of international economic relations is being formed.

Various aspects of the problem are disclosed in existing sources of research literature. The fundamental principles of managing the processes of international cooperation and integration of small and medium-sized businesses are laid in the works of such Russian scientists as S. A. Belyaev, O. E. Ibragimov, R. V. Kashbraziev, V. V. Klochkov, E. A. Makarchuk, O. V. Nikulina, F. A. Podgaysky, M. V. Strelkov, as well as in the works of foreign authors, including experts of the World Bank Z. Wu, P. Kumar, D. Skilling and P. S. Tewari (Tewari et al., 2018), etc.

Barriers to the development of international cooperation and integration for small and medium-sized businesses in Russia are the risks of reverse effects of international integration: the risk of reducing economic independence (including company merger), the risk of reducing competitiveness and organizational barriers, for example, high requirements for placing investments in special economic zones that exceed the turnover of small and medium-sized businesses (Ostrovsky, 2019).

Currently, in the regions of the Russian Federation, the state management of cooperation and integration processes in entrepreneurship focuses on the interests of the region, which leads to the establishment of high entry barriers and inaccessibility of international cooperation and integration for small and medium-sized businesses. This restricts competition, hinders the innovative development of the regional economy, and impedes Russia's social and economic progress.

\section{Methodology}

When studying international cooperation and integration of small and medium-sized businesses, various groups of economic and mathematical methods are widely used. In the process of investigating the problems the following methods were used: logical and comparative analysis, synthesis, classification information, etc.

The intensification of activities in the framework of international cooperation and integration of small and medium-sized businesses in Russia is associated with their high adaptability, as well as increased interest in international cooperation. The wide spread of international cooperation and integration in the sphere of small and medium-sized businesses is to strengthen market positions, which helps to increase competitiveness and expand sales markets (for exports). It is necessary to define priority types of international cooperation-international cooperation and integration-within the framework of foreign economic activity policy of organizations. Improving the quality of process management should ensure the creation of a highly protectionist business climate for these priority types in tax, customs, financial, material, labour, investment and information aspects.

The paper uses materials from official statistics and analytics on international cooperation and integration of small and medium-sized businesses of the Federal State Statistics Service (Rosstat) and the Ministry of Economic Development of the Russian Federation. The research was carried out on the platform of a systematic approach using general scientific methods: analysis, synthesis, induction, deduction, sociological survey, expert assessments, graphical visualization of data, as well as a set of methods of economic statistics. 
Prospects of international cooperation and integration for small and medium business in Russia are connected with the creation of an inclusive environment for international integration and protection of interests of subjects of small and average business. A threat to the development of international cooperation and integration for small and medium-sized businesses in Russia is the continued focus on maximizing the benefits for the region through the international integration of large businesses.

\section{Results}

Currently, more and more attention is paid to the development of small and medium-sized businesses, which greatly contributes to maintaining a competitive environment in the economy, gives it the necessary flexibility, actively implements innovative processes, expands the social layer of entrepreneurs, and provides the main part of the increase in employment. In the light of the globalization of the world economy in recent years, small and medium-sized enterprises in many countries that have mastered new forms and methods of international cooperation have also begun to prove their right to participate in the system of foreign economic activity. Russia has chosen to expand international cooperation in order to strengthen its position on world markets.

Participants in the foreign economic activity of the Stavropol territory in 2019 carried out export operations in the amount of more than 1,196 million us dollars, which is $11 \%$ more than the volume of the corresponding period in 2018 (Figure 1).

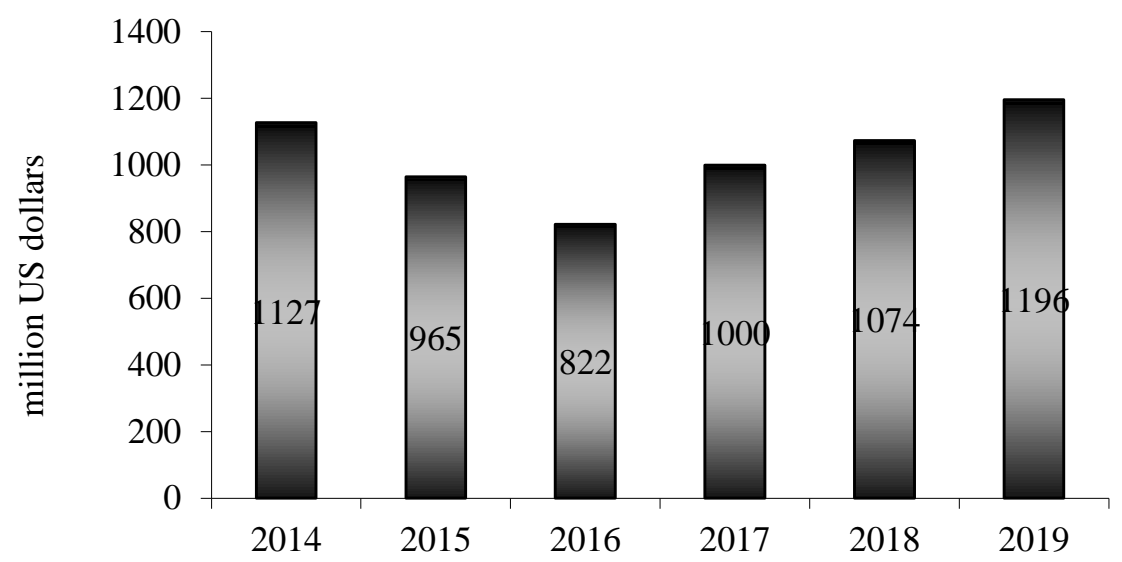

Figure 1. Export of the Stavropol territory from 2014 to 2019, million US dollars (Federal Customs Service of Russia, 2020)

In 2019 , the share of exports in the trade turnover amounted to more than $66 \%$ of the export value. When carrying out export operations, participants of the foreign economic activity of the Stavropol territory focused on deliveries to foreign countries, with a volume of deliveries amounting to 791.55 million US dollars, with a share in exports of $66.56 \%$. Accordingly, the CIS countries accounted for 397.66 million US dollars with a share of $33.44 \%$ in exports (Figure 2). 


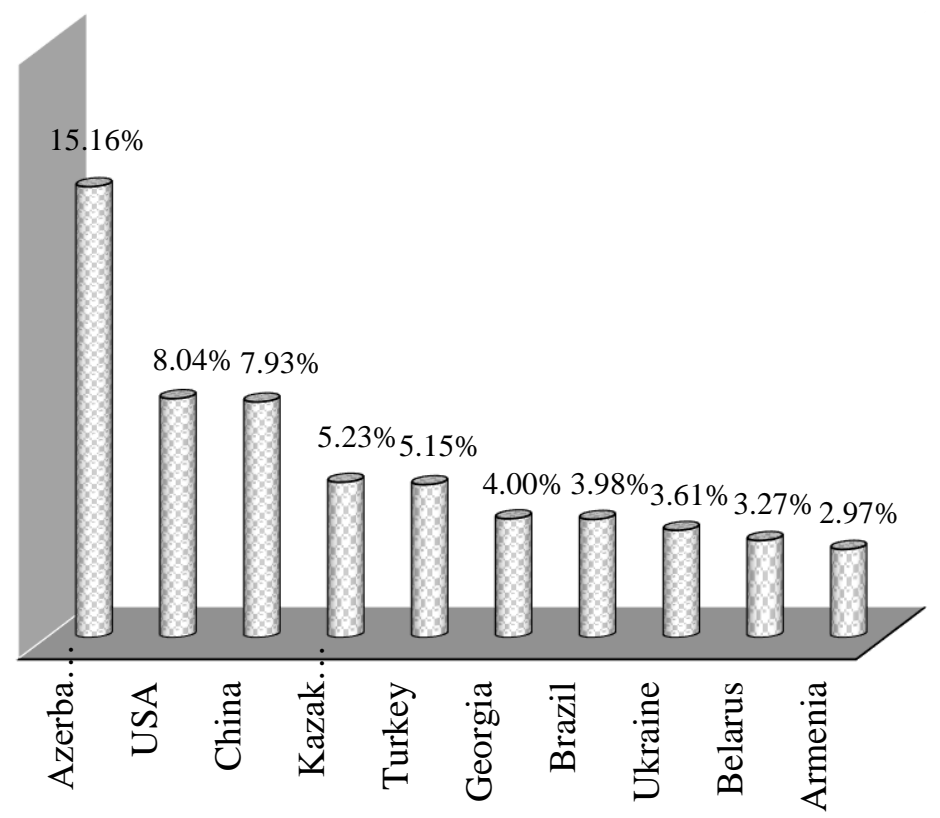

Figure 2. Export share of the Stavropol territory by countries-counterparts in 2019 (Federal Customs Service of Russia, 2020)

Thus, the geography of exports from the region is wide. Azerbaijan and Turkey account for a large share of exported goods (more than 15\%). However, this indicator varies depending on the types of products. In Table 1, we analyze the commodity structure of exports from the Stavropol territory at the beginning of 2019 .

The commodity structure of exports shows that over the past three years there has been a trend of rapid growth in the volume of exported metals and products made from them. Enterprises of the Stavropol territory sell ferrous metals. Most often they are exported to Turkey, Algeria, Egypt, Armenia and Tunisia. There is also a tendency to reduce the volume of exported oils and fats (sunflower oil, margarine, etc.). The largest share in the commodity structure of exports of the Stavropol territory is occupied by products of the chemical industry (41.2\%), of which $73 \%$ are fertilizers delivered mainly to the United States. Thus, the export structure of the Stavropol territory is quite diverse and dynamic. Food products, metals, fertilizers, products of the timber industry and the chemical industry, and many others.

The Stavropol region should increase its export volume to 2.5 billion rubles by the end of 2024. The main export items will be agricultural products and industrial production.

According to the Department of the Federal State Statistics service for the North Caucasus Federal district (2020) the commodity structure of exports of the Stavropol territory is formed by chemical products, food products and agricultural raw materials, metals and products made from them, mineral products, machinery, equipment and vehicles. In terms of supporting the export of Stavropol producers, with the assistance of the Ministry of Economic Development of the region, 27 entrepreneurs engaged in foreign economic activities signed 30 export contracts worth $\$$ 17.5 billion (Ministry of Economic Development of the Stavropol territory: official website). 
Table 1. Commodity structure of exports from the Stavropol territory

\begin{tabular}{|l|c|c|c|c|c|c|}
\hline \multicolumn{1}{|c|}{$\begin{array}{c}\text { Group of } \\
\text { products }\end{array}$} & $\begin{array}{c}2016, \\
\text { millions } \\
\text { of } \\
\text { dollars }\end{array}$ & $\begin{array}{c}2017, \\
\text { millions } \\
\text { of dollars }\end{array}$ & $\begin{array}{c}\text { Change } \\
\text { for 2017, } \\
\%\end{array}$ & $\begin{array}{c}2018, \\
\text { millions } \\
\text { of } \\
\text { dollars }\end{array}$ & $\begin{array}{c}\text { Change for } \\
2018, \%\end{array}$ & $\begin{array}{c}\text { Share } \\
\text { for } \\
2018, \\
\%\end{array}$ \\
\hline Animal products & 32,5 & 58,1 & +79 & 76,7 & +32 & 7,1 \\
\hline Plant products & 154 & 190 & +23 & 142 & -25 & 13,2 \\
\hline Fats and oils & 23,9 & 4,4 & -82 & 2,5 & -42 & 0,2 \\
\hline $\begin{array}{l}\text { Food products, beverages, } \\
\text { tobacco }\end{array}$ & 41,8 & 60,4 & +45 & 38,3 & -37 & 3,6 \\
\hline Mineral product & 28,2 & 24,8 & -12 & 55,7 & +125 & 5,2 \\
\hline $\begin{array}{l}\text { Chemical } \\
\text { products }\end{array}$ & 405 & 424 & +5 & 442 & +4 & 41,2 \\
\hline $\begin{array}{l}\text { Plastics, rubber and natural } \\
\text { rubber }\end{array}$ & 45,3 & 71,7 & +58 & 87 & +21 & 8,1 \\
\hline Leather and fur products & 4,7 & 2,7 & -42 & 3,7 & +35 & 0,3 \\
\hline Wood and wood products & 1,1 & 1,6 & +45 & 1,2 & -29 & 0,1 \\
\hline Textile & 9,3 & 8,4 & -9 & 8,3 & -2 & 0,8 \\
\hline $\begin{array}{l}\text { Stone, ceramic and glass } \\
\text { products }\end{array}$ & 5,2 & 8,8 & +68 & 10,9 & +24 & 1 \\
\hline Jewelry & 39,4 & 85,3 & +117 & 66,7 & -22 & 6,2 \\
\hline Metals and metal products & 4,6 & 22,7 & +389 & 98,3 & +333 & 9,2 \\
\hline $\begin{array}{l}\text { Machinery, equipment and } \\
\text { instrumentation }\end{array}$ & 6,1 & 11 & +81 & 12,3 & +12 & 1,1 \\
\hline Transport & 1,1 & 1,6 & +42 & 1,8 & +9 & 0,2 \\
\hline $\begin{array}{l}\text { Tools and devices, clock } \\
\text { and watches }\end{array}$ & 12,8 & 8,7 & -32 & 8,5 & -2 & 0,8 \\
\hline Various industrial products & 5,9 & 13,2 & +122 & 17,6 & +33 & 1,6 \\
\hline Total: & 822 & 1000 & +22 & 1074 & +7 & 100 \\
\hline
\end{tabular}

In addition to commodity exports, the Stavropol territory is developing exports of services. Transport services include not only servicing by any means of transport, but also a number of related operations: loading and unloading, storage and warehousing, packing and repacking of goods, towing, wiring of ships, driving of aircraft, operation and cleaning of transport equipment, rescue operations and related services, as well as commission fees related to passenger and cargo transportation.

Foreign companies were provided with transport services worth $\$ 5.8$ million, the main part of which is the export of aircraft maintenance services.

The potential of the region is huge. In general, there are many Russian companies that could successfully conquer world markets. However, now they often build their own model, focusing on the regions of Russia.

In a particular case, the nearest neighbors. About one-fifth of Russia's gross domestic product, and in many regions of the Russian Federation, a third or more of the gross regional product is created by small and medium-sized enterprises. In 2016, the Russian government approved the strategy for the development of small and mediumsized businesses in the Russian Federation for the period up to 2030. One of the objectives of this strategy is to improve the system of support for export activities of small and medium-sized enterprises.

The importance of small and medium-sized enterprises for achieving and maintaining high economic performance has traditionally been emphasized and is a subject of increased interest among policy makers in national governments and international institutions in 
both developed and developing countries. This is due to the fact that in most countries, small and medium-sized businesses make up the vast majority of business entities, are the main source of job creation and largely determine the size of GDP and the rate of economic growth.

As a result of content analysis and systematization of materials of existing scientific research and publications on international cooperation and integration of enterprises (Belyaev \& Nadjafova, 2017; Ibragimov, 2017; Klochkov \& Rozhdestvenskaya, 2016; Makarchuk, 2015; Nikulina, 2016; Podgaisky, 2017; Strelkov, 2016), we define international cooperation of small and medium-sized businesses as a process of combining domestic small and medium-sized businesses with foreign businesses, in which:

- foreign business entities can be small, medium and large-sized;

- business entities that are located at different stages of the value chain (at the same stage or at different stages) can be combined;

- different goals may be pursued by the subjects of the association and different consequences may arise (access to foreign markets, monopolization of foreign markets, growth of competitiveness in foreign markets);

- various areas of economic activity (production, financial, marketing, management) of business entities can be combined;

- various forms (horizontal and vertical integration and cooperation, as well as reorganization) and their corresponding types of associations can be used.

The quality of the management of international cooperation and integration is a factor of systemic organization of foreign economic activity of subjects of small and medium-sized enterprises in ensuring the success of the export-import partnerships, competitiveness of small and medium-sized business, efficiency of business activities in foreign markets. At the same time, the economic aspect considers the quality of management as an integrated characteristic of the enterprise, its ability to successfully conduct business.

International cooperation and integration processes can both create new opportunities for development and constitute threats to small and medium-sized businesses. In this regard, a separate aspect of state management of the development of small and mediumsized businesses is the management of the processes of their international cooperation and integration, whch is aimed at achieving maximum benefits from them for the small and medium-sized businesses themselves and for the domestic economy.

Issues of foreign economic activity of small and medium-sized businesses are addressed in many legal documents of Russia. The priority of the development of export activities of domestic small and mediumsized businesses is emphasized in the Strategy for the Development of Small and MediumSized Businesses in the Russian Federation for the period up to 2030, approved by Order of the Government of the Russian Federation No. 1083-R of June 2, 2016. The establishment of export-oriented small and medium-sized businesses in Russia, engaged in high-tech sectors of the economy, is stated as the main way to implement this strategy.

The Report of the State Council of the Russian Federation about measures on development of small and medium enterprises in the Russian Federation for 2015 among the main directions of the state support of small and average business in the near and medium future are the support of the demand for the products of small and medium entrepreneurship and the development of new markets, through improved system support for their export activities.

The development strategy of JSC "Russian export centre" until 2019 as a way to implement the main direction of the strategic 
development of the Russian Federation "international cooperation and export" provides measures to ensure favorable conditions for exports carried out by small and medium-sized businesses.

In these documents, the foreign economic activity of small and medium-sized businesses is considered as a promising way and a key direction of Russia's transition from a raw material to a high-tech model of development, which allows ensuring high and stable competitiveness of the domestic economy in the long term. At the same time, the emphasis is placed on the export activities of small and medium-sized businesses as the most preferred form of their foreign economic activity.

However, the specificity of small and medium-sized businesses associated with their low resource availability and increased risk component of their activities makes independent access to foreign industry markets the least attractive and almost inaccessible form of their foreign economic activity.

It is important to recognize that a more promising alternative is their participation in the processes of international cooperation and integration, since it allows them to achieve tangible results and share risks between the participants of an international integration or cooperative association of business entities with minimum effort and expense.

We have identified the following features that are characteristic of small and medium-sized businesses, which play an important role in the process of their international integration and cooperation, and determine the features of state policy in the field of support for small and medium-sized businesses in the format of international cooperation and integration.

One of the main features is the lack of financial resources. On the one hand, minimum requirements for financial resources provide favorable conditions for the creation of new small and medium-sized enterprises, thereby contributing to the achievement and maintenance of high business activity in the economy. On the other hand, the lack of financial resources causes numerous difficulties in the economic activities of small and medium-sized businesses, such as:

- limited opportunities in the field of crisis management due to the inability to create reserve funds for full-scale insurance of business risks;

- low creditworthiness due to the lack or minimum amount of available funds (low solvency and liquidity) and the minimum amount of profit and profitability;

- $\quad$ preferential use of working capital and leased fixed assets is minimal, since the acquisition of own fixed assets, which are usually more expensive and subject to rapid moral and physical deterioration, is not available;

- innovation activity is usually reduced to the development and implementation of organizational, managerial and marketing innovations, since technological innovations are the most expensive and therefore unavailable.

Another feature that hinders the development of international cooperation and integration of small and medium-sized businesses is the lack of human resources necessary for successful foreign economic activity. Here, restrictions on the number of employees as one of the criteria for small and medium-sized businesses, as well as the lack of financial resources for small and medium-sized businesses to attract highly qualified production workers are important.

The third feature which holds back the development of international cooperation and integration for small businesses is a high dependence on transport logistics. Unlike large businesses that can acquire foreign assets and create new business units abroad, small and medium-sized businesses do not have this opportunity. 
Along with the listed specific features of international cooperation and integration of small and medium-sized businesses, there is a high dependence on the latest information and communication technologies. The location of small and medium-sized businesses on the territory of the Russian Federation significantly complicates the process of their direct ("live") communication with both foreign economic entities that are partners in integration or cooperation, and with foreign consumers.

Another feature should be recognized as the lack and complexity of small and mediumsized businesses to obtain information about the opportunities for international integration and cooperation, including information about the potential benefits of international integration and cooperation. Most small and medium-sized businesses have limited capabilities in the field of strategic management, which is usually carried out by their owners themselves, who do not have sufficient knowledge and experience of international integration and cooperation and therefore do not take into account this direction of enterprise development.

An additional constraint on this path is the high dependence on state support. Small and medium-sized businesses are in great need of incentives (for example, tax preferences) for international integration and cooperation.

In order to promote the development of export potential, on December 24, 2018, the Presidium of the Presidential Council for Strategic Development and Priority Projects approved the project (program) "International Cooperation and Export". To achieve task 1 of section 4.1. "Orientation of industrial and trade policy, including the state support mechanisms, to achieve international competitiveness of Russian goods (works, services) in order to ensure their presence in foreign markets", with the maximum involvement of the subjects of the Russian Federation, normative legal acts have been adopted that establish, starting from 2019:
- measures to support organizations aimed at improving the international competitiveness of Russian industrial products, including by reducing the cost of transporting products, at the federal and regional levels;

- long-term contracts containing the obligation of enterprises to achieve the numerical performance efficiency of subsidies, including export volume (Passport of a national project (programme) "International Cooperation and Export", 2018).

Within the framework of the national project "International Cooperation and Export", the federal project "System measures for the development of international cooperation and export" is also being implemented, which includes the following tasks:

1) "Reduction of administrative procedures and barriers in the field of international trade, including the abolition of redundant requirements for export licensing and currency control, organization (by 2021) of interaction between participants in foreign economic activity and subjects of international trade with public authorities, including regulatory authorities and other organizations in electronic form by the principles of "one window";

2) "Organization (by 2021) of interaction of participants of foreign economic activity and subjects of international trade with public authorities, including regulatory authorities and other organizations in electronic form on the principle of "one window" on the basis of the digital platform of the Russian Export Center (REC)»;

3) "Completion of a flexible range of export support financial instruments (by 2021), including export and equity financing, leasing and longterm support measures"; 
4) "Creation of a unified system of export promotion institutions that provides for the modernization of trade representations of the Russian Federation in foreign countries", etc.

In addition, REC together with the Russian Ministry of Industry and Trade and the Ministry of Economic Development, are creating a Unified system for promoting exports abroad and in the regions of the Russian Federation.

In addition, the zero VAT rate for the export of works and services is effective from July 1 within the frame of the national project "International Cooperation and Export". The corresponding changes were made to the Tax Code with the direct participation of REC. Because the recipient of Russian services is located abroad, it is quite logical to exempt the exporter from paying VAT, especially since he previously had to pay the appropriate taxes within the country from the cost of creating his export product, for example, when purchasing the necessary equipment (The project "International Cooperation and Export" interview with Andrey Slepnev, 2019).

At the level of the Stavropol territory, the regional project "System measures for the development of international cooperation and export of the Stavropol territory" was approved. Its goal is to ensure the increase in the number of export-oriented enterprises covered by export support measures to 483 by the end of 2024 by implementing a set of measures to improve mechanisms for stimulating export activity in the Stavropol territory by actively promoting and positioning Stavropol commodity producers as companies that create products of the highest quality (Passport of the regional project "System measures for the development of international cooperation and exports of the Stavropol territory", 2018).

In the course of implementing the project, the following progress has been made in 2019:
- REC and the Government of the Stavropol territory were signed a Memorandum of cooperation on export activities;

- the schedule for the implementation of the Regional export standard 2.0 has been approved. It includes the development and creation of acceleration programs for exporters, participation in a unified system for promoting products for export, and the creation of a database of exporters;

- the "Club of exporters of the Stavropol territory" was created and operates on the basis of the Union "The Stavropol territory Chamber of Commerce and Industry";

- the annual plan of exhibition and forum events, as well as the plan of international activities of the region, has been developed and approved. Export-oriented enterprises and exporters were involved in the implementation of these plans.

In the context of increasing competition and cross-border trade, countries that have not been able to integrate into modern models for organizing supplies and providing support services do not receive competitive advantages. The delivery costs of their products are higher, and the quality of services is lower than that of competitors who have mastered digital channels. Therefore, the Internet portal "Made in the Stavropol territory" has been created and is regularly updated with new information in the Internet at the following address: http://madeinsk.ru.

On October 28, 2019, at REC meeting in Zheleznovodsk, it was said that by 2024 , the Stavropol territory will increase exports to $\$$ 2 billion due to state support measures.

\section{Conclusion}

Thus, over the past few years, there has been a tendency to increase the volume of exports from the Stavropol territory. The structure of 
exports of the Stavropol region are quite diverse and dynamic. Food products, metals, fertilizers, products of the timber industry and the chemical industry, and many other things, including services, are exported. The government of the Russian Federation is implementing projects that will allow achieving mass international cooperation and integration of small and medium-sized businesses.

Currently, participants in foreign economic activity (FEA), only at the stage of planning export deliveries, have to contact about twenty departments, filling out and receiving about seventy different forms of documents. At the same time, the level of automation differs significantly between different departments, which affects the speed of services. Feedback from these agencies is also not always transparent, which makes it difficult to understand the current status of the application. At the same time, the exporter is often forced to provide the same documents to each agency, including in paper form. At the moment, the Russian Federation is developing an information system "One window", which should provide businesses with convenient access to public services in one place in electronic form to solve the listed problems (Enin, 2019).

Also, in the course of consultations with representatives of business and public authorities, the Member States of the Eurasian Economic Union, the problems and challenges that Eurasian participants of digital trade face both in the domestic and foreign markets were identified:

- the problems that require regulatory harmonization, reducing barriers, or simplifying administrative procedures;

- systemic problems related to the global competitiveness of systems and processes implemented in the Union with the risk of increasing the flow of added value to third countries in the process of trade (Recommendation of the EEC Council "On the Concept of creating

$$
\begin{aligned}
& \text { conditions for the digital } \\
& \text { transformation of industrial } \\
& \text { cooperation within the Eurasian } \\
& \text { Economic Union and the digital } \\
& \text { transformation of industry in the } \\
& \text { Member States of the Union", 2018). }
\end{aligned}
$$

The analysis of existing problems has shown the need to implement a set of joint actions aimed at:

- developing digital cross-border services, encouraging an increase in the share of services in goods, and ensuring a balance in regulating the market for digital services and related products;

- formation of digital assets and digitization of goods and services created in the country;

- development of digital trade channels between states and creation of services that provide digital trade based on digital platforms;

- infrastructure development of the digital trade, and promotion of technologies.

In the interests of involving small and medium-sized businesses in the processes of international cooperation and integration and implementing a new quality of socioeconomic progress, scientists propose a model of state incentives for the development of these processes, which regulates each regional international integration association of enterprises in three directions:

1) assessment of interest, promotion of integration, organizational support;

2) maintaining low barriers to entry into the regional international integration association of enterprises for large and foreign businesses;

3) stimulating competition and preventing the negative impact of large and foreign businesses on small and medium-sized businesses.

The quality of managing the processes of foreign economic activity is manifested in increasing the competitiveness of the enterprise in the foreign market. This results 
in massive international integration and cooperation of regional entrepreneurship, a significant increase in business and innovation activity of entrepreneurship in the regional economy of Russia, as well as increasing competition and increasing exports of Russian entrepreneurship.

\section{Acknowledgment}

The reported study was funded by RFBR, project number 19-310-90078.

\section{References:}

Belyaev, S. A. \& Nadjafova, M. N. (2017). Influence of international integration and globalization on Russian enterprises. Innov: electronic scientific journal, 4(33), 37.

Department of the Federal State Statistics Service for the North Caucasus Federal district (2020). Commodity structure of exports and imports. Retrieved from: https://stavstat.gks.ru/storage/mediabank/\%D0\%A2\%D0\%BE\%D0\%B2\%D0\%B0\%D1\%80 \%D0\%BD\%D0\%B0\%D1\%8F\%20\%D1\%81\%D1\%82\%D1\%80\%D1\%83\%D0\%BA\%D1\%8 2\%D1\%83\%D1\%80\%D0\%B0\%20\%D1\%8D\%D0\%BA\%D1\%81\%D0\%BF\%D0\%BE\%D1 $\% 80 \% \mathrm{D} 1 \% 82 \% \mathrm{D} 0 \% \mathrm{~B} 8 \% 20 \% \mathrm{D} 0 \% \mathrm{~B} 8 \% 20 \% \mathrm{D} 0 \% \mathrm{~B} 8 \% \mathrm{D} 0 \% \mathrm{BC} \% \mathrm{D} 0 \% \mathrm{BF} \% \mathrm{D} 0 \% \mathrm{BE} \% \mathrm{D} 1 \%$ 80\%D1\%82\%D0\%B0(1).pdf (accessed 12 March 2020).

Enin, O. (2019). "One window" is a multifunctional centre for potential exporters and importers". Retrieved from: https://finance.rambler.ru/other/41847961-oleg-enin-odno-oknoeto-mfts-dlya-potentsialnyh-eksporterov-i-importerov/?updated (accessed 18 November 2019).

Federal Customs Service of Russia (2020). Foreign trade of subjects of the Federal district. Retrieved from: http://sktu.customs.ru/ (accessed 12 March 2020).

Ibragimov, O. E. (2017). Organizational and economic features of integration of small enterprises in the innovation process of enterprises of the military-industrial complex of the region. Fundamental research, 11(1), 215-219.

Kashbraziev, R. V. (2012). International cooperation in the system of economic categories. Retrieved from: https://cyberleninka.ru/article/n/mezhdunarodnaya-kooperatsiya-v-sistemeekonomicheskih-kategoriy (accessed 24 November 2019).

Klochkov, V. V., \& Rozhdestvenskaya, S. M. (2016). Restrictions of international cooperation and efficiency of using the experimental base of Russian applied science. Management and business administration, 2, 131-140.

Makarchuk, E. A. (2015), Transnationalization of joint ventures as a form of corporate integration in international business: theoretical aspect. Business inform, 4(1), 47-51.

Ministry of Economic Development of the Stavropol territory: official website. Retrieved from: http://www.stavinvest.ru/ (accessed 11 April 2020).

Nikulina, O. V. (2016). International cooperation as a mechanism for interaction of industrial enterprises in the field of innovation. National interests: priorities and security, 4(337), 88102.

Ostrovsky, V. I. (2019). The role of international cooperation and integration of small and medium-sized businesses in the implementation of a new quality of social and economic progress in Russia. Humanities of the South of Russia, 8(4), 257-268. Retrieved from: https://www.isras.ru/index.php?page_id=2384\&id=6671 (accessed 18 November 2019). 
Passport of the national project (program) "International Cooperation and Export", (2018), Retrieved from: https://stavregion.ru/_/cms_page_media/7093/\%D0\%9C\%D0\%B5\%D0 \%B6\%D0\%B4\%D1\%83\%D0\%BD\%D0\%B0\%D1\%80\%D0\%BE\%D0\%B4\%D0\%BD\%D0 $\% \mathrm{~B} 0 \% \mathrm{D} 1 \% 8 \mathrm{~F} \% 20 \% \mathrm{D} 0 \% \mathrm{BA} \% \mathrm{D} 0 \% \mathrm{BE} \% \mathrm{D} 0 \% \mathrm{BE} \% \mathrm{D} 0 \% \mathrm{BF} \% \mathrm{D} 0 \% \mathrm{~B} 5 \% \mathrm{D} 1 \% 80 \% \mathrm{D} 0 \% \mathrm{~B} 0 \%$ D1\%86\%D0\%B8\%D1\%8F\%20\%D0\%B8\%20\%D1\%8D\%D0\%BA\%D1\%81\%D0\%BF\%D0 \%BE\%D1\%80\%D1\%82.pdf (accessed 18 November 2019).

Passport of the regional project "System measures for the development of international cooperation and export of the Stavropol territory" (2018). Retrieved from: https://stavregion.ru/_/cms_page_media/7042/sistem.pdf (accessed 18 November 2019).

Podgaisky, F. A. (2017). Opportunities for entrepreneurship in the processes of international cooperation. Podolsky scientific bulletin, l(1), 100-103.

Recommendation of the EEC Council "On the Concept of creating conditions for the digital transformation of industrial cooperation within the Eurasian Economic Union and the digital transformation of industry in the Member States of the Union", (2018). Retrieved from: http://docs.cntd.ru/document/551911031 (accessed 18 November 2019).

Strelkov, M. V. (2016). Integration of enterprises in the Russian and world economy. Economics and society, 12-2 (31), 1177-1184.

Tewari, P. S., Skilling, D., Kumar, P., \& Wu, Z. (2013). Competitive small and medium enterprises: a diagnostic to help design smart SME policy, World Bank Group. Retrieved from: http://documents.worldbank.org/curated/en/534521468331785470/Competitive-smalland-medium-enterprises-a-diagnostic-to-help-design-smart-SME-policy (accessed 16 November 2019).

The project "International Cooperation and Export" interview with Andrey Slepnev (2019). Retrieved from: https://exporteram.com/proekt-mezhdunarodnaya-kooperaciya-i-eksportintervyu-andreya-slepneva/ (accessed November 18, 2019).

The Stavropol region exports will double by 2024 (2019). Retrieved from: https://stv24.tv/novosti/eksport-stavropolskih-tovarov-udvoitsya-k-2024-godu/ (accessed 24 November 2019).

The Stavropol territory will increase exports of industrial and agricultural products (2019). Stavropol Pravda. Retrieved from: https://stapravda.ru/20191121/stavropolskiy_ kray_uvelichit_eksport_promyshlennoy_i_selhozprodu_141314.html (accessed 24 November 2019).

\section{Vladislav I. Ostrovskiy}

Southern Federal

University,

Rostov-on-Don, Russia

ostrovskiyvlad@mail.ru 